KONTINU: Jurnal Penelitian Didaktik Matematika

Vol: 2, No.2, Oktober 2018

\title{
PEMBELAJARAN SOCRETES KONTEKSTUAL TERHADAP KEMAMPUAN BERPIKIR KRITIS SISWA POKOK BAHASAN ARITMATIKA SOSIAL
}

\author{
Sri Lestari Pratiwi ${ }^{1)}$, Mochamad Abdul Basir ${ }^{2)}$, Nila Ubaidah $^{3)}$ \\ Pendidikan Matematika, Universitas Islam Sultan Agung ${ }^{1,2), 3)}$ \\ aliyatiwi5@gmail.com¹), abdulbasir@unissula.ac.id ${ }^{2)}$, nilaubaidah@unissula..ac.id ${ }^{3)}$
}

\begin{abstract}
Abstrak. Penelitian ini bertujuan untuk mengetahui pengaruh sikap belajar siswa dengan pembelajaran socrates kontekstual terhadap kemampuan berpikir kritis, mengetahui ratarata siswa dengan pembelajaran socrates mencapai ketuntasan, dan mengetahui kemampuan berpikir kritis siswa pada pembelajaran socrates kontekstual lebih dari ratarata dengan pembelajaran konvensional siswa SMP Negeri 6 Semarang pada pokok bahasan aritmatika sosial. Sampel dalam penelitian ini diambil secara cluster random sampling, terpilih kelas VII F sebagai kelas eksperimen dengan pembelajaran socrates kontekstualdan kelas VII G sebagai kelas kontrol dengan pembelajaran konvensional, yaitu ceramah dan penugasan, serta kelas VIII E ialah kelas uji coba. Teknik pengumpulan data menggunakan teknik tes, angket, dan dokumentasi.Data hasil penelitian dianalisis dengan uji normalitas, uji homogenitas, uji pengaruh, uji ketuntasan dan uji perbandingan rata-rata. Hasil penelitian menunjukkan bahwa: (1). Siswa kelas eksperimen dengan pembelajaran socrates kontekstual mendapat pengaruh sikap belajar terhadap kemampuan berpikir kritis sebesar $69,7 \%$. (2). Kemampuan berpikir kritis siswa yang diberikan pembelajaran socrates kontekstual mencapai KKM 70 pada pokok bahasan aritmatika sosisal dengan hasil ratarata kemampuan berpikir kritis siswa sebesar 81,90. (3). Rata-rata kemampuan berpikir kritis siswa yang menerima pembelajaran socrates kontekstual yaitu sebesar 81,90 dari pada rata - rata kemampuan berpikir kritis siswa yang menerima pembelajaran konvensional dengan rata-rata sebesar 76,13.
\end{abstract}

Kata Kunci: Socrates Kontekstual, Berpikir Kritis, Sikap Belajar

\begin{abstract}
This study aims to determine the effect of student learning attitudes with learning contextual socrates on critical thinking skills, knowing the average student with learning Socrates achieved completeness, and knowing students' critical thinking skills in learning contextual socrates more than the average with conventional learning of junior high school students 6 Semarang in the subject of social arithmetic. The sample in this study was taken by cluster random sampling, selected class VII $F$ as an experimental class with learning contextual Socrates and class VII G as a control class with conventional learning, namely lectures and assignments, and class VIII E was a trial class. Data collection techniques using test techniques, questionnaires, and documentation. The results of the research data were analyzed by normality test, homogeneity test, effect test, completeness test and average comparison test. The results showed that: (1). Experimental class students with contextual learning socrates got the influence of learning attitudes toward critical thinking skills by $69.7 \%$. (2). Critical thinking skills of students who are given contextual learning socrates achieve KKM 70 on the subject of sausage arithmetic with the results of the average student's critical thinking skills of 81.90. (3). The average critical thinking ability of students who receive contextual learning Socrates is equal to 81.90 than the average critical thinking ability of students who receive conventional learning with an average of 76.13 .
\end{abstract}

Keywords: Socrates Contextual, Critical Thinking, Attitude Of Learning 
KONTINU: Jurnal Penelitian Didaktik Matematika

Vol: 2, No.2, Oktober 2018

\section{PENDAHULUAN}

Belajar memiliki dua definisi yaitu "...acquisition of any relatively permanent change in behaviour as a result of a practice and experience." atauperolehan perubahan tingkah laku yang relatif menetap sebagai akibat latihan dan pengalaman dan "process of aquiring responses as a result of special practice." atau proses memperoleh respon-respon sebagai akibat adanya latihan khusus (Syarifuddin, 2011). Pembelajaran dapat memberikan perubahan perilaku siswa dalam rangka mencapai tujuan pendidikan. Pada hakikatnya, pembelajaran menghendaki adanya perubahan cara berpikir, perkembangan potensi, perbaikan sikap pada diri siswa. Siswa yang telah menempuh pembelajaran, tentunya akan mendapatkan pola pikir yang berbeda dibandingkan dengan sebelum mendapat pembelajaran.Matematika merupakan subjek penting dalam masyarakat modern yang berguna di sekolah-sekolah, tempat kerja, bisnis dan untuk pengambilan keputusan pribadi. Matematika dipandang sebagai bahasa dalam penggunaan sehari-hari baik di pasar, sekolah atau bahkan di rumah. Matematika merupakan dasar untuk kemakmuran nasional dalam menyediakan alat untuk memahami sains, teknik, teknologi dan ekonomi (Chukwuyenum, 2013). Cara berpikir siswa dalam menyelesaikan masalah matematika sangat penting,supaya siswa mampu menyaring informasi, memilih layak atau tidak suatu kebutuhan, mempertanyakan kebenaran yang terkadang dibaluti dengan kebohongan, dan segala hal yang dapat membahayakan kehidupan siswa (Syahbana, 2012). Harapannya, pola pikir tersebut dapat direalisasikan berupa sebuah tindakan yang dapat membawa perubahan dalam diri siswa. Oleh karena itu, pembelajaran akan lebih baik jika dalam prakteknya berkaitan dengan proses tanya jawab dan dikaitakan dengan kehidupan seharihari.

Hasil pengamatan yang dilakukan di SMP Negeri 6 Semarang diketahui bahwa tingkat kemampuan berpikir kritis dan sikap belajar siswa dalam menyelesaikan persoalan matematika masih kurang. Siswa kurang memahami makna atau signifikasi dari pertanyaan yang diberikan oleh guru, situasi, dan kejadian yang dialami. Siswa hanya melihat suatu masalah kurang berinteraksi terhadap masalah tersebut. Hubungan kemauan siswa untuk ikut dalam suatu stimulus masih rendah. Siswa juga kesulitan mengidentifikasi hubunganhubungan inferensial dan aktual dari pertanyaan, pernyataan, dan bentuk representasi penilaian, alasan-alasan, informasi dan opini yang ada. Selain itu, siswa juga kesulitan menaksir pernyataan yang merupakan laporan atau deskripsi dari persepsi atau representasi. Sebagian siswa juga masih kurang tepat dalam mengidentifikasi jawaban untuk membuat kesimpulan yang tepat. Akibatnya dalam mengerjakan soal siswa hanya 
KONTINU: Jurnal Penelitian Didaktik Matematika

Vol: 2, No.2, Oktober 2018

menjawab semaunya saja dan kadang langkah-langkah dalam menyelesaikan soal kurang jelas dan tidak sesuai.

Sikap belajar dapat merubah siswa dalam proses perubahan tingkah laku atau proses menerima terhadap kehidupan sekitar untuk memperoleh suatu perubahan tingkah laku secara keseluruhan. Shodri (2014) mengemukakan empat sikap yang terjadi dalam suatu pembelajaran yaitu (1) Hubungan kemauan siswa untuk ikut dalam suatu stimulus khusus yang biasa disebut dengan receiving. (2) Responding, siswa tidak hanya melihat suatu masalah tetapi juga berinteraksi terhadap masalah tersebut. (3) Menilai (valuing) ini berkenaan dengan nilai yang dikenakan siswa terhadap suatu obyek tertentu. (4) Character yang meliputi banyak kegiatan, tetapi lebih besar ditekankan pada kenyataan bahwa tingkah laku menjadi ciri khas setiap siswa.

Ennis (Jayadipura, 2014) juga mengungkapkan bahwa berpikir kritis adalah berpikir yang masuk akal, reflektif, dan difokuskan pada pengambilan keputusan. Berpikir kritis lebih banyak pada kendali otak kiri dengan fokus menganalisis dan mengembangkan berbagai kemungkinan dari masalah yang dihadapi. Facione (Karim, 2015) mengungkapkan empat kecakapan berpikir kritis utama yang terlibat di dalam proses berpikir kritis, yaitu berpikir untuk (1) Menginterpretasi, memahami, mengekspresikan makna atau signifikansi dari berbagai pengalaman, situasi, data, kejadian-kejadian, penilaian. (2) Analisis, mengidentifikasi hubungan-hubungan inferensial yang dimaksud dan aktual diantara pernyataan-pernyataan, pertanyaan-pertanyaan, konsep-konsep, deskripsi-deskripsi atau bentuk-bentuk representasi lainnya dimaksudkan untuk mengekspresikan penilaian, pengalaman-pengalaman, alasan-alasan, informasi atau opiniopini. (3) Evaluasi, menaksir kredibilitas pernyataan-pernyataan yang merupakan laporan atau deskripsi dari persepsi, pengalaman, situasi, penilaian, kepercayaan atau opini seseorang, serta menaksir kekuatan logis dari hubungan inferensial atau diantara pernyataan, deskripsi, pertanyaan, atau bentuk representasi lainnya. (4) Inferensi, mengidentifikasi dan memperoleh unsur yang diperlukan untuk membuat kesimpulan yang masuk akal, membuat dugaan dan hipotesis, mempertimbangkan informasi yang relevan serta menyimpulkan konsekuensi dari data, situasi, pertanyaan atau bentuk representasi lainya.Berpikir kritis tergolong pada hard skill matematik tinggi (Sumarmo, 2014).

Penelitian yang dilakukan oleh beberapa ahli menunjukkan kualitas peningkatan kemampuan berpikir kritis siswa yang mendapatkan pembelajaran matematika dengan menggunakan pembelajaran berbasis masalah lebih baik dari pada siswa yang pembelajaran matematika secara konvensional. Kesimpulan ini memberikan implikasi 
KONTINU: Jurnal Penelitian Didaktik Matematika

Vol: 2, No.2, Oktober 2018

bahwa pembelajaran berbasis masalah layak digunakan oleh guru bidang studi matematika di sekolah sebagai alternatif mengembangkan kemampuan berpikir kritis (Sunaryo, 2014).

Salah satu pembelajaran yang berbasis masalah, mengandung proses bertanya dan mengaitkan permasalahan dengan kehidupan sehari-hari adalah Pembelajaran Socrates Kontekstual. Pembelajaran Socrates Kontekstual merupakan pembelajaran dengan metode Socrates di dalam pendekatan Kontekstual. Jones, dkk (Yunarti, 2011) mendefinisikan Metode Socrates sebagai sebuah metode yang merangsang siswa untuk menganalisis suatu masalah dengan sebuah analogi dan berpikir kritis tentang suatu argumen. Sedangkan pembelajaran dengan pendekatan kontekstual adalah suatu strategi pembelajaran yang menekankan kepada proses keterlibatan siswa secara penuh untuk dapat menemukan materi yang dipelajari dan menghubungkannya dengan situasi kehidupan nyata sehingga mendorong siswa untuk dapat menerapkannya dalam kehidupan mereka (Sanjaya, 2011). Maka, pembelajaran Socrates Kontekstual adalah pembelajaran yang mengarahkan siswa pada suatu konsep kemudian menghubungkan dengan permasalahan yang kompleks dengan memberikan pertanyaan-pertanyaan yang mengarahkan siswa untuk berpikir kemudian dapat menemukan suatu konsep.

Pembelajaran socrates kontekstual diharapkan dapat membantu kemampuan berpikir kritis siswa. pembelajaran socrates berisi tanya jawab yang bagus digunakan untuk membimbing dan memperdalam tingkat pemahaman yang berkaitan dengan aritmatika sosial, sehingga siswa mendapat pemikirannya sendiri dan hasil konflik kognitif yang terpecahkan (Johnson, 2010). Metode socrates kontekstual memiliki tujuan utama pada aspek-aspek pengembangan kemampuan berpikir kritis.

Berdasarkan uraian tersebut maka dilakukan penelitian tentang pembelajaran socrates kontekstual terhadap kemampuan berpikir kritis siswa pada materi aritmatika sosial.

\section{METODE PENELITIAN}

Untuk mengetahui pengaruh Pembelajaran Socrates Kontekstual terhadap Kemampuan Berpikir Kritis siswa pada penelitian ini menggunakan pendekatan penelitian kuantitatif. Penelitian kuantitatif merupakan penelitian yang sistematis, terencana, dan terstruktur dengan jelas. Penelitian kuantitatif penelitian yang berlandaskan filsafat positivisme, digunakan untuk meneliti populasi dan sampel (Sugiyono, 2016). Penggunaan penelitian kuantitatif ini dilakukan mengingat masalah yang diteliti adalah masalah yang merupakan titik penelitian sudah jelas dan dilakukan pada populasi yang luas sehingga hasil penelitian kurang mendalam, jelas langkah-langkah penelitian dan hasil yang diharapkan, 
KONTINU: Jurnal Penelitian Didaktik Matematika

Vol: 2, No.2, Oktober 2018

dimana desainnya lebih spesifik, jelas, rinci, ditentukan secara mantap sejak awal, dan menjadi pegangan langkah demi langkah.

Penelitian ini merupakan penelitian kuantitatif yang menggunakan metode eksperimen dalam penelitian ini menggunakan posttest only control design. Dalam desain ini terdapat dua kelompok yang masing-masing dipilih secara random. Kelompok pertama diberi perlakuan dan kelompok yang lain tidak. Kelompok yang diberi perlakuan disebut kelompok eksperimen dan kelompok yang tidak diberi perlakuan disebut kelompok kontrol (Sugiyono, 2016). Peneliti menggunakan metode eksperimen yang bertujuan untuk melihat hubungan sebab akibat, dimana perlakuan yang diberikan terhadap variabel bebas dapat dilihat hasilnya pada variabel terikat. Kelas VIII E digunakan untuk kelas uji coba dan dari hasil random cluster kelompok kelas eksperimen kelas VII F dengan menggunakan pembelajaran socrates kontekstual diberi perlakuan (X1) dan kelompok kelas kontrol kelas VII G dengan menggunakan pembelajaran konvensional diberi perlakuan (X2). Dalam penelitian peneliti akan melakukan penelitian tentang pengaruh pembelajaran Socrates Kontekstual terhadap kemampuan berpikir kritis siswa.

Instrumen penelitian dan mengumpulkan data-data. Untuk memperoleh data yang diharapkan dalam penelitian ini, maka menggunakan metode tes kemampuan berpikir kritis, metode angket sikap belajar, dan metode dokumentasi. Perhitungan skor kemampuan berpikir siswa berdasarkan pada indikator menurut Facione (Karim, 2015)

\begin{tabular}{|c|c|c|}
\hline No. & Indikator Umum & Indikator \\
\hline 1. & Menginterpretasi & $\begin{array}{l}\text { Memahami masalah yang ditunjukkan dengan } \\
\text { menulis diketahui maupun yang ditanyakan soal } \\
\text { dengan tepat. }\end{array}$ \\
\hline 2. & Menganalisis & $\begin{array}{l}\text { Mengidentifikasi hubungan-hubungan antara } \\
\text { pernyataan-pernyataan, dan konsep-konsep yang } \\
\text { diberikan dalam soal yang ditunjukkan dengan } \\
\text { membuat model matematika dengan tepat dan } \\
\text { memberi penjelasan dengan tepat. }\end{array}$ \\
\hline 3. & Mengevaluasi & $\begin{array}{l}\text { Menggunakan strategi yang tepat dalam } \\
\text { menyelesaikan soal, lengkap dan benar dalam } \\
\text { melakukan perhitungan. }\end{array}$ \\
\hline 4. & Menginverensi & Membuat kesimpulan dengan tepat. \\
\hline
\end{tabular}

Tabel 1. Indikator Berpikir Kritis Menurut Facione

Nilai persentase $=\frac{\text { skor perolehan }}{\text { skor maksimal }} \times 100 \%$ 
KONTINU: Jurnal Penelitian Didaktik Matematika

Vol: 2, No.2, Oktober 2018

Adapun hasil analisis butir soal uji coba instrumen dapat dilihat pada tabel berikut.

\begin{tabular}{clcccc}
\hline \multicolumn{2}{c}{ Item Soal } & $\mathbf{1}$ & $\mathbf{2}$ & $\mathbf{3}$ & $\mathbf{4}$ \\
\hline \multirow{2}{*}{ Validitas } & r hitung & 0,618 & 0,633 & 0,774 & 0,664 \\
& $\mathrm{r}$ table & 0,3550 & 0,3550 & 0,3550 & 0,3550 \\
& Kriteria & Valid & Valid & Valid & Valid \\
& Alpha & 0,647 & & & \\
Reliabilitas & Kriteria & Tinggi & & & \\
& Keterangan & Soal Reliabel & & & \\
Daya & $\mathrm{P}_{\mathrm{A}}$ & 13,25 & 11,38 & 13,88 & 10,88 \\
pembeda & $\mathrm{P}_{\mathrm{B}}$ & 9,88 & 8,25 & 7,88 & 7,5 \\
& DP & 0,21 & 0,20 & 0,38 & 0,21 \\
& Kriteria & Cukup & Cukup & Baik & Cukup \\
tingkat & $\overline{\mathrm{X}}$ & 11,19 & 9,52 & 11,16 & 9,55 \\
kesukaran & SMI & 16 & 16 & 16 & 16 \\
Soal & $\mathrm{P}$ & 0,70 & 0,60 & 0,70 & 0,60 \\
& Keterangan & Sedang & Sedang & Sedang & Sedang \\
Keterangan & & Digunakan & Digunakan & Digunakan & digunakan \\
\hline
\end{tabular}

Tabel 2. Analisis Instrumen Tes Kemampuan Berpikir Kritis

Berdasarkan hasil uji coba instrumen tes dapat kesimpulkan bahwa hasil kemampuan berpikir kritis pokok bahasan aritmatika sosial, soal uji coba instrumen dinyatakan valid karena $r_{\text {hitung }}>r_{\text {tabel }}$ dapat dilihat pada tabel 3 Soal dikatakan reliabel jika nilai Cronbach's Alpha pada tabel 3.5 Reliability Statistics dengan SPSS 19.0 diperoleh nilai 0,647 dimana nilai ini ditafsirkan dengan kriteria koefisien reliabilitas soal pada tabel 3.5 bahwa butir soal tes reliabilitas diterima. Daya pembeda diterima jika nilai DPsesuai klarifikasi daya pembeda maka soal 1 diterima karena klarifikasi cukup, soal 2 diterima karena klarifikasi kurang baik, soal 3 diterima karena klarifikasi baik, soal 4 diterima karena klarifikasi kurang baik dan tingkat kesukaran soal dikatakan sedang sesuai tabel 3.6 interpretasi nilai indeks kesukaran karena soal 1, 2, 3,4 berada pada interprestasi 0,31-0,70 maka soal pada kategori sedang. Dengan demikian soal tes hasil kemampuan berpikir kritis pokok bahasan aritmatka sosial dapat digunakan sebagai instrumen tes penelitian.

\section{HASIL DAN PEMBAHASAN}

Hasil uji normalitas menggunakan SPSS 19.0 diperoleh bahwa nilai sig. Kolmogorov-Smirnov untuk kelas eksperimen adalah 0,052 dan kelas kontrol 0,200. Karena kedua kelas memiliki nilai Sig. KS $>0,05$, maka $H_{0}$ diterima. Hal ini menunjukkan nilai tes kemampuan berpikir kritis siswa kelas eksperimen berdistribusi normal. Hasil uji homogenitas menggunakan Uji Levene berbantuan SPSS 19.0 diperoleh nilai Sig adalah sebesar 0,426. Karena nilai Sig. 0,426>0,05, maka $H_{0}$ diterima. Jadi dapat disimpulkan bahwa kedua sampel memiliki varians yang sama atau kedua kelas homogen. 
KONTINU: Jurnal Penelitian Didaktik Matematika

Vol: 2, No.2, Oktober 2018

Deskripsi statistik rata-rata sikap belajar dan nilai akhir kelas eksperimen siswa dihitung dengan SPSS 19.0 dengan rata-rata nilai sikap belajar sebesar 67,53 dan nilai ratarata kelas eksperimen 81,90. Analisis uji linier sederhana antara nilai kelas eksperimen dan sikap belajar siswa terhadap kemampuan berpikir kritis siswa tersebut menunjukkan bahwa nilai $R$ Square sebesar 0,697 atau 69,7\%. R-Square dalam hal ini 69,7\% kemampuan berpikir kritis (Y) dapat dijelaskan oleh variabel nilai sikap belajar (X) sedangkan sisanya dijelaskan oleh variabel lain. Ini berarti $69,7 \%$ variasi yang terjadi didalam Y dapat dijlaskan $X$ melalui regresi $\hat{Y}=18,485+0,939 X$ sedangkan $30,3 \%$ dipengaruhi oleh variabel lain.

Berdasrkan hasil perhitungan uji t satu sampledengan SPSS 19.0 diketahui rata-rata kemampuan berpikir kritis siswa dengan pembelajaran socrates kontekstualsebesar 81,90 dan sig (2-tailed) sebesar $0,000<0.05$ hal ini meneunjukkan bahwa rata-rata kemampuan berpikir kritis siswa yang menerima pembelajaran socrates kontekstual mencapai ketuntasan KKM 70.

Berdasrkan hasil perhitungan Group Statistics dengan SPSS 19.0 didapat rata-rata kemampuan berpikir kritis siswa dengan pembelajaran socrates kontekstual sebesar 81,90 dan rata-rata kemampuan berpikir kritis siswa dengan pembelajaran Konvensional sebesar 76,13 selisih rata-rata antara keduanya cukup signifikan yaitu 5,77.

\section{Pengaruh Sikap Belajar Terhadap Kemampuan Berpikir Kritis Siswa}

Berdasarkan hasil analisis uji statistik data akhir kelas eksperimen dengan berbantuan SPSS 19.0 yaitu dengan uji regresi linier sederhana menunjukkan bahwa korelasi antara sikap belajar dan nilai akhir kemampuan berpikir kritis siswa kelas eksperimen sebesar 0,835 yang berarati korelasi kedua variabel tersebut tinggi, korelasi positif hubungan antara sikap belajar dengan pembelajaran socrates kontekstual dan nilai akhir kemampuan berpikir kritis tersebut searah, sikap belajar mempengaruhi 69,7\% terhadap nilai akhir kemampuan berpikir kritis siswa.

Pada analisis ragam di dalam regresi linier sederhana nilai sig. adalah 0,000 kurang dari $\alpha 0,05$ jadi model regresi yang diperoleh layak untuk digunakan dalam memprediksi nilai akhir tes kemampuan berpikir kritis, dari koefisien regresi didapat persamaan regresi $\widehat{Y}=18,485+0,939$ X yang menunjukkan 18,485 nilai konstanta jika tidak ada sikap belajar maka nilai akhir tes kemampuan berpikir kritis akan mencapai 18,485 dan setiap peningkatan 1 sikap belajar akan meningkatkan nilai akhir tes kemampuan berpikir kritis sebesar 0,939. Hal tersebut sejalan dengan teori belajar skinner dalam Mahmud (1989) tingkah laku bukanlah sekedar respon terhadap stimulus, tetapi suatu tindakan yang 
KONTINU: Jurnal Penelitian Didaktik Matematika

Vol: 2, No.2, Oktober 2018

disengaja atau operant. Operant conditioning yang sering disebut dengan pengkondisian operan yang merupakan penguatan perilaku positif maupun negatif dimana perilaku tersebut dapat terulang kembali maupun menghilang sesuai dengan keinginan individu tersebut.

Koefien regresi $\mathrm{t}$ hitung $>\mathrm{t}$ tabel yaitu 8,019 > 2,002 maka terdapat pengaruh sikap belajar siswa dalam pembelajaran socrates kontekstual terhadap kemampuan berpikir kritis siswa pada pokok bahasan aritmatika sosial.

\section{Ketuntasan Nilai Rata-Rata Kemampuan Berpikir Kritis Siswa}

Uji t satu sampel menunjukkan bahwa rata-rata kemampuan berpikir kritis pada kelas eksperimen sebesar 81,90, rata-rata kemampuan berpikir kritis siswa pada materi aritmatika sosial menggunakan pembelajaran socrates kontekstual dapat mencapai ketuntasan yaitu KKM 70. Hal ini disebabkan kelas eksperimen diterapkan pembelajaran yang dapat menarik perhatian siswa agar suasana belajar mengajar tidak membosankan dikelas yaitu dengan adanya pembelajaran socrates kontektual diharapkan siswa dapat menunjukan kemampuan berpikir kritis dalam menyelesaikan permasalah, berdiskusi atau bertukar informasi dengan temannya, sehingga rata-rata kemampuan berpikir kritis siswa dengan menggunakan pembelajaran socrates kontekstual mencapai ketuntasan KKM 70.

Teori yang mendukung dalam penelitian ini adalah teori belajar vygotsky yang menekankan pada scaffolding memberikanbantuan penuh kepada anak dalam tahap awal pembelajaran kemudian berangsur-angsur dikurangi dan memberi kesempatan kepada anak untuk mengambil alih tanggung jawab semakin besar (Yohanes, 2010). Kemudian teori belajar kontruktivisme dimana guru sebagai fasilitator yang mendukung siswa untuk merumuskan ide, mengemukakan pendapat, dan memberikan kesempatan kepada siswa untuk bertanya maupun membuat kesimpulan (Dienna, 2016).

\section{Perbandingan Kelas Eksperimen dan Kelas Kontrol}

Hasil analisis yang dilakukan peneliti, setelah dilakukan uji t dua sampel menggunakan SPSS 19.0 (uji perbedaan rata-rata) diperoleh nilai rata-rata kelas eksperimen 81,90 dengan Sig. (2-tailed) sebesar 0,000<0,05 maka perbedaan bermakna secara signifikan pada probabilitas 0,05 , berdasarkan kriteria pengujian hipotesis, maka $\mathrm{H}_{\mathrm{o}}$ ditolak dan terima $\mathrm{H}_{\mathrm{a}}$, artinya terdapat perbedaan kemampuan berpikir kritis pada kelas eksperimen dan kelas kontrol. Hal ini menunjukkan bahwa rata-rata kemampuan berpikir kritis matematika siswa pada kelas eksperiemen lebih baik dari pada kelas kontrol. 
KONTINU: Jurnal Penelitian Didaktik Matematika

Vol: 2, No.2, Oktober 2018

Hal tersebut disebabkan kelas eksperimen menggunakan pembelajaran socrates kontektual terhadap kemampuan berpikir kritis yang mengajak siswa untuk merespon setiap permasalahan dalam pembelajaran dikelas, sehingga agar kemapuan berpikir kritis meningkat maka kegiatan belajar mengajar dikelas tidak hanya berjalan satu arah saja tetapi berjalan dua arah yaitu guru dan siswa aktif. Berbeda dengan kelas kontrol yang dalam pembelajarannya hanya mengunakan pembelajaran konvensional guru sebagai pusat dalam pembelajaran sehingga tidak merangsang siswa untuk mencari solusi dari permasalahan dalam belajar sehingga tidak dapat meningkatkan kemampuan berpikir kritis siswa.

Penelitian relevan yang dapat mendukung yaitu hasil penelitian Penelitian yang dilakukan oleh Rahma (2017) yang berjudul "Analisis Berpikir Kritis Siswa dengan Pembelajaran Socrates Kontekstual di SMP N 1 Padangratu Lampung Tengah" menunjukkan bahwa rata-rata kemampuan berpikir kritis siswa kelas VII F termasuk kedalam kategori cukup ini terlihat dari hasil rata-rata tes kemampuan berpikir kritis siswa yaitu sebesar 65,43 dan yang lebih dominan adalah siswa dengan presentase 46,4\% dari 28 siswa.

Akhir dari pembahasan ini diketahui bahwa secara umum terdapat pengaruh sikap belajar siswa dalam pembelajaran socrates kontekstual terhadap kemampuan berpikir kritis siswa. Dan proses penerapan pembelajaran socrates kontekstual untuk meningkatkan kemampuan berpikir kritis siswa terlaksana dengan cukup baik dan membawa dampak positif bagi siswa dalam pembelajaran, nilai rata-rata kemampuan berpikir kritis siswa dengan pembelajaran socrates kontekstual dapat mencapai ketuntasan yaitu KKM 70.

\section{PENUTUP}

Berdasarkan hasil analisis dan pembahasan penelitian di bab IV, dapat ditarik kesimpulan, (1) Pengaruh sikap belajar siswa kelas eksperimen yang mendapat perlakuan dengan pembelajaran socrates kontekstual terhadap kemampuan berpikir kritis siswa pada pokok bahasan aritmatika sosial yaitu sebesar 69,7\%.. (2) Kemampuan berpikir kritis matematika siswa kelas VII SMP Negeri 6 Semarang tahun ajaran 2017/2018 yang dikenai pembelajaran socrates kontekstual mencapai ketuntasan yaitu KKM 70 pada materi Aritmatika sosial dengan hasil rata-rata kemampuan berpikir kritis siswa sebesar 81,90. (3) Kemampuan berpikir kritis siswa kelas VII SMP Negeri 6 Semarang tahun ajaran 2017/2018 yang menggunakan pembelajaran socrates kontekstual lebih baik dengan hasil rata-rata 
KONTINU: Jurnal Penelitian Didaktik Matematika

Vol: 2, No.2, Oktober 2018

sebesar 81,90 dari pada kemampuan berpikir kritis siswa yang menggunakan pembelajaran konvensional dengan hasil rata-rata sebesar 76,13.

\section{DAFTAR PUSTAKA}

Chukwuyenum, Asuai Nelson. (2013). Impact of Critical thinking on Performance in Mathematicsamong Senior Secondary School Students in Lagos State. IOSR Journal of Research \& Method in Education (IOSR-JRME), e-ISSN: 2320-7388,p-ISSN: 2320-737XVolume 3 No 5 PP 18-25.

Jayadipura, Yadi. (2014). MengukurKemampuan Berpikir Kritis Matematik. ProsidingSeminar Nasional Pendidikan Matematika ISSN 2355/0473, Vol. 1, hal. 18.

Johnson, Elaine B. (2010). Contextual Teaching and Learning. Bandung: Kaifa.

Karim, Normaya. (2015). Kemampuan Berpikir Kritis Siswa dalam Pembelajaran Matematika dengan Menggunakan Model Jucama di Sekolah Menengah Pertama. EDU-MAT Jurnal Pendidikan Matematika, Vol. 3, No. 1,Hal. 92-104.

Rahma, Siti. (2017). Analisis Berpikir Kritis Siswa dengan Pembelajaran Socrates Kontekstual di SMP N 1 Padang Ratu. Skripsi. Lampung: Unila.

Shodri, sa'id. (2014). Studi Komparasi Sikap Belajar Dalam Pelaksanaan Pendidikan Agama Islam Antara Siswa Yang Berasal Dari SD Bernuansa Islami Dengan SD Umum di SMP Negeri 06 Salatiga tahun ajaran 2013/2014. Skripsi. Salatiga: STAIN Salatiga.

Sanjaya, Wina. (2011). Strategi pembelajaran berorientasi standrat proses pendidikan. Jakarta: Kencana.

Sugiyono. (2016). Metode Penelitian Pendidikan Pendekatan Kuantitatif, Kualitatif dan $R \&$ D. Bandung: Alfabeta.

Sumarmo, U., Hidayat, W., Zukarnaen, R., Hamidah., \& Sariningsih, R. (2012). Kemampuan Dan Disposisi Berpikir Logis, Kritis, Dan Kreatif Matematik. Jurnal Pengajaran MIPA, Vol.17, No.1, Hal. 17-33.

Sunaryo, Y. (2014). Model Pembelajaran Berbasis Masalah Untuk Meningkatkan Kemampuan Berpikir Kritis dan Kreatif Siswa SMA di Kota Tasikmalaya. Jurnal Pendidikan dan Keguruan, Vol.1, No.2, Hal.41-50. 
KONTINU: Jurnal Penelitian Didaktik Matematika

Vol: 2, No.2, Oktober 2018

Syahbana, A. (2012). Peningkatan Kemampuan Berpikir Kritis Matematis SMP Melalui Pendekatan Contextual Teaching and Learning. Edumatica, Volume 2, Nomor 1, page 45-57.

Syarifuddin, Ahmad. (2011). Penerapan model pembelajaran cooperative belajar dan faktor-fakor yang mempengaruhinya. Jurnal Nasional TA'DIB. Vol. 16, No. 1, Hal. 113-136.

Widiantari, N. K., I, M. S., \& Nym., K. (2016). Analisis Kemampuan Berpikir Kritis Siswa Kelas IV dalam Pembelajaran Matematika. e-Jurnal PGSD Universitas Pendidikan Ganesha, page 1-11.

Yohanes, Rudi Santoso. (2010). Teori Vygotsky dan Implikasinya Terhadap Pembelajaran Matematika. Jurnal Widya Warta No. 02 Tahun XXXIV / Juli 2010 ISSN 0854-1981 hal.127-135.

Yunarti, Tina. (2011). Pengaruh Metode Socrates terhadap Kemampuan dan Disposisi Berpikir Kritis Siswa.Disertasi, tidak dipublikasikan. Bandung: UPI. 